\title{
The trend of geriatric health research and the challenge of health system translation in Nigeria
}

\author{
Musa Abubakar Kana \\ From Health Services Research: Evidence-based practice \\ London, UK. 1-3 July 2014
}

\begin{abstract}
Background
Nigeria is expected to be the nation with the 11th highest population of older persons by 2015 . This demographic transition will have implications for the medical care services. Currently, there is no geriatric social health insurance policy nor comprehensive geriatric healthcare services in the country. The minimal health system response may be due to lack of comprehensive knowledge of geriatric disease burden, pattern and healthcare needs. This paper aims to describe the trend and pattern of geriatric health research publications, and to review the current geriatric health policies in Nigeria.
\end{abstract}

\section{Materials and methods}

A systematic review of published reports in PubMed was performed for the period of January 1990 to April 2014. The review of current geriatric health policies was conducted by document analyses of an annotated national bibliography on digitized health policies and guidelines.

\section{Results}

A total of 38 policies and guidelines of the Federal Ministry of Health were reviewed and none of them targeted geriatric health. The systematic review identified 52 eligible studies out of 3519 studies. Twenty-five studies (48\%) were community-based studies, twenty (38\%) were conducted in hospital settings, while only one was carried out in an old people's home and four were narrative literature reviews. Twelve studies $(23 \%)$ were done in a rural area, $24(46 \%)$ in an urban area and $11(21 \%)$ report findings from both locations.

One study reported the health of the elderly and economic policies (1), elderly destitution (1), health implication of ageing (1), attitude to ageing (2), care for the elderly (3), quality of life and life satisfaction (3), nutrition

\footnotetext{
Department of Community Medicine, Faculty of Medicine, Kaduna State
} University, Kaduna, Kaduna State, Nigeria

(c) 2014 Kana; licensee BioMed Central Ltd. This is an Open Access article distributed under the terms of the Creative Commons Attribution License (http://creativecommons.org/licenses/by/4.0), which permits unrestricted use, distribution, and reproduction in any medium, provided the original work is properly cited. The Creative Commons Public Domain Dedication waiver (http:// creativecommons.org/publicdomain/zero/1.0/) applies to the data made available in this article, unless otherwise stated.
(2) and physical activity (1). The morbidity pattern reported from the reviewed articles were as follows: medical morbidities (8), geriatric emergencies and admissions (2), dental problems (5), surgical morbidities (1), nosocomial infection (1), mental health morbidities (6), orthopaedic (2), otorhinolaryngology (3), urology (1) and visual morbidities (5).

\section{Conclusions}

The findings underscore a geriatric health research and policy needs. It is recommended that resources be invested into collaborative research for the development and implementation of evidence based geriatric health policies.

Published: 7 July 2014

doi:10.1186/1472-6963-14-S2-P3

Cite this article as: Kana: The trend of geriatric health research and the challenge of health system translation in Nigeria. BMC Health Services Research 2014 14(Suppl 2):P3.

Submit your next manuscript to BioMed Central and take full advantage of:

- Convenient online submission

- No space constraints or color figure charges

- Immediate publication on acceptance

- Inclusion in PubMed, CAS, Scopus and Google Scholar

- Research which is freely available for redistribution Submit your manuscript at
www.biomedcentral.com/submit C Biomed Central
- Thorough peer review 